\title{
7. MIGRATED MULTICHANNEL SEISMIC-REFLECTION RECORDS ACROSS THE PERU CONTINENTAL MARGIN'
}

\author{
Roland von Huene ${ }^{2}$ and John Miller ${ }^{3}$
}

\begin{abstract}
We examined multichannel seismic records CDP-1, CDP-2, CDP-3, 1017, and records obtained during the site survey for Leg 112 to evaluate stratigraphy, tectonic evolution, and the structural character of the active margin offshore of Peru.

From the reprocessed records we learned that the regionally uniform structure of the margin between $4^{\circ} \mathrm{S}$ and $14^{\circ} \mathrm{S}$ is modified by local tectonism. Common elements are crust of continental affinity beneath the middle and upper slope and an accretionary complex below the lower slope. The forearc basins have a varied tectonic history, which led to considerable differences in subsidence history and deformational style. Compressional tectonics dominate the front of the margin, whereas extension accounts for deformation landward of the midslope area.
\end{abstract}

\section{INTRODUCTION}

During three cruises undertaken to study marine geology of plate convergence, multichannel seismic-reflection data were acquired across the Peruvian margin. During the earliest cruise in 1973, data were acquired by Seiscom-Delta under contract for the Nazca Plate Project. Three lines (called CDP-1, -2, and -3) were placed off southern Peru at about $11^{\circ} \mathrm{S}$ (Hussong and Wipperman, 1981), off central Peru at $9^{\circ} \mathrm{S}$ (Kulm et al., 1981), and off northern Peru at $5.5^{\circ} \mathrm{S}$ (Shepherd and Moberly, 1981). These data were acquired using a DFS-3 digital seismic system at a sampling rate of $4 \mathrm{~ms}$ with record lengths up to $13 \mathrm{~s}$. The sound source consisted of two 300 -in. ${ }^{3}$ and two 1000 -in. ${ }^{3}$ air guns that were fired at 35 -m intervals and were detected on a hydrophone streamer with a 1600 -m-long active array composed of 24 hydrophone groups. The original processing was done at 12-fold (Kulm et al., 1981), and between 1984 and 1986 each of the three records was reprocessed at 24 -fold and migrated (von Huene et al., 1985; Kulm et al., 1986; Miller et al., 1986; and von Huene et al., in press). The sequence used in the reprocessing is described in detail elsewhere (Miller et al., 1986) and is not given here. Unmigrated CDP-1, -2 , and -3 were the primary records used for selecting the proposed Leg 112 drill sites. Since publication of these reprocessed northern and central records, they have been processed further and the southern record was migrated just one week before the beginning of Leg 112. The latest processed versions are presented here.

Complementary publication of seismic-reflection data was made in preparation for Leg 112 drilling. Interpretation of the unmigrated Nazca Plate Project data, combined with some industry data in the southern and central areas, was published in the Ocean Margin Drilling Program data compilations (Thornburg, 1985). These efforts were followed by the site surveys for Leg 112 , during which a grid of multichannel data with low seismic source energies was acquired by the University of Hawaii. The University of Hawaii data were migrated and are reported in the accompanying articles by Moore and Taylor and by Ballesteros et al. (this volume). The University of Hawaii site surveys also included

\footnotetext{
${ }^{1}$ Suess, E., von Huene, R., et al., 1988. Proc. ODP, Init. Repts., 112: College Station, TX (Ocean Drilling Program).

2 U.S. Geological Survey, Branch of Pacific Marine Geology, 345 Middlefield Rd., M/S 999, Menlo Park, CA 94025.

3 U.S. Geological Survey, Box 25046, Denver Federal Center, Denver, CO
}

swath-type bathymetric mapping (SeaMARC) and sampling (Hussong et al; Kulm et al., this volume).

A third survey was conducted by the Jean Charcot just three months before Leg 112 (Bourgois et al., 1986; Pautot et al., 1986). A primary purpose of this survey was to supplement the University of Hawaii site-survey information for the review of drilling safety by the Pollution Prevention and Safety Panel of JOIDES. The seismic lines were laid perpendicular to the central and northern Nazca Plate Project records (CDP-2 and -3) at proposed drill sites to check for structural closure. The "portable" instrument system consisted of a DFS-5 digital recorder, a 1200-m-long hydrophone streamer with 24 geophone groups, and a single 540-in. ${ }^{3}$ air gun. Enough compressed air was available for shots at $50-\mathrm{m}$ intervals, and data were thus recorded at 12 -fold. These records were processed through migration, which was completed after stacking.

In addition to these records, a record in the southern area released to ODP by Shell International was reprocessed through migration. The quality of this record was excellent because of the 3000-m-long streamer, 60-channel digital recording, and tuned 1200 -in. ${ }^{3}$ seismic source (Lehner et al., 1983). Only a part of that record is shown here as its length is much greater than the available space and it reaches from the East Pacific Rise to the coast.

In previous studies of geophysical data, researchers concluded that the Peruvian margin consists of continental crust, a transition zone, and an accretion complex adjacent to the trench axis. Various authors have differed only in where the continental crust ends in an $80-\mathrm{km}$ zone. In the following seismic records, the zone of uncertainty or transition was narrowed to $10 \mathrm{~km}$ or less. One tectonic objective of Leg 112 was to study this transition, its structural style, and its origin. Another was to study the subsidence history of the margin, particularly the disparate subsidence histories of the Lima and Trujillo basins. Rocks obtained by conventional sampling contain benthic foraminifers indicating that the former subsided rapidly, whereas the latter remained relatively stable (Kulm et al., 1981; Kulm et al., 1984).

\section{DESCRIPTION OF FEATURES IN SEISMIC RECORDS}

\section{Southern Record (CDP-1)}

CDP-1 begins just seaward of the Salaverry Basin (Fig. 1), then crosses Lima Basin and a complex structure beneath the lower slope that includes the change from continental crust to 


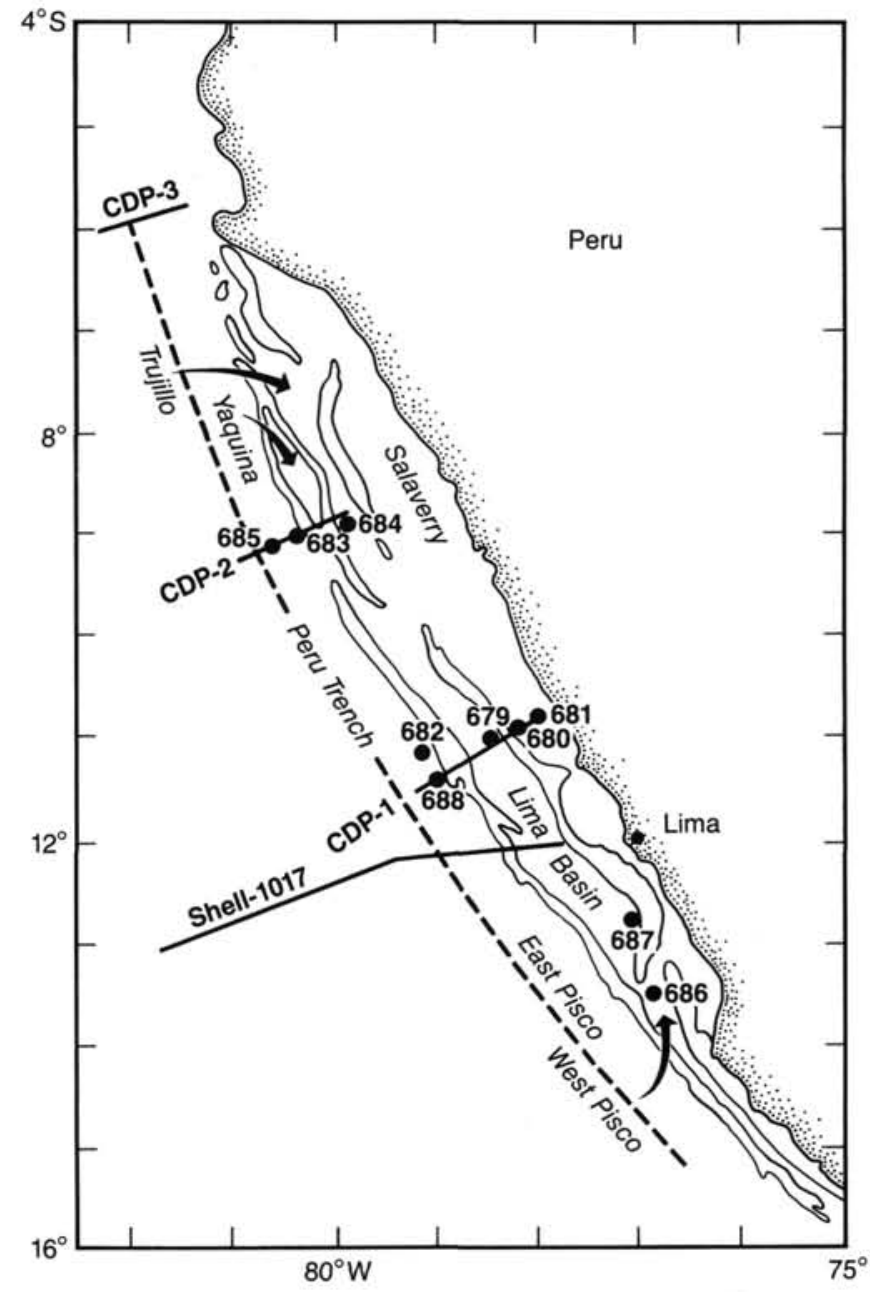

Figure 1. The Peruvian Continental Margin showing the location of forearc basins and seismic lines. Dots indicate location of drill sites.

an accretionary complex. The structure of the Lima Basin fill and its sedimentary history is described by Ballesteros et al. (this volume). We only comment on features in the seismic basement below the fill that were not imaged in their data.

The floor of Lima Basin is composed of a profound unconformity below which seismic resolution diminishes (Figs. 2 and 3). Across that unconformity, seismic velocity changes from 1.9 to $6.0 \mathrm{~km} / \mathrm{s}$ (Hussong et al., 1976; Hussong and Wipperman, 1981), which indicates a great change in the consolidation of rocks above and below. The dipping beds cut by the unconformity have an apparent thickness of up to $1 \mathrm{~km}$. Coherent strataform reflections can be seen in the high-velocity seismic basement until it is obscured by the first water-bottom multiple. The abrupt velocity contrast, profound erosion, and regional extent (Ballesteros et al., this volume) indicate subaerial, rather than submarine, erosion.

The seaward flank of the Lima Basin falls along a narrow segment of steeper slope that Thornburg (1985) used as the division between the upper and middle slopes. In the deep subsurface, this slope corresponds to a normal fault that juxtaposes basement on its landward side against a 1-km-thick sequence of sedimentary rock on its seaward side. This sediment sequence is a more distal part of the one eroded from beneath Lima Basin (Figs. 2 and 3). The angular unconformity that was seen beneath Lima Basin no longer exists, and the stratigraphy becomes conformable. Thus, the division here between the upper and middle slopes was once a paleoshoreline.
The middle-slope reflections become increasingly obscured seaward until few coherent reflections remain at the juncture between the middle and lower slopes. The most visible tectonic features of the middle slope are numerous small normal faults. Below the middle- to lower-slope junctures are coherent reflections from subducting sediment.

The lower slope has a structure peculiar to the front of a convergent margin. Beneath the seafloor are reflections that dip west or seaward (Fig. 3). This reflective sequence is well illustrated in the unmigrated record, and its base was interpreted as the top of fractured crystalline continental crust, based on the $\sim 5-\mathrm{km} / \mathrm{s}$ velocity of the underlying rock (Hussong and Wipperman, 1981). At the front of the margin, a landward-dipping reflective sequence cuts the seaward-dipping one. Its low seismic velocity and structure indicate an accretionary complex (Hussong and Wipperman, 1981). Below the accretionary complex, a sequence of subducting strata occurs above the igneous oceanic crust.

\section{Southern Record (1017)}

Record 1017 is about $10 \mathrm{~km}$ south of CDP-1 and has a similar tectonic structure. The unconformity that lies beneath the Lima Basin is clearly imaged, as is the stratification in some underlying rocks (Fig. 2). The surface of the unconformity is cut by normal faults having small vertical displacements. The depth of erosion along the unconformity decreases along the seaward flank of the basin, indicating removal of about $1.5 \mathrm{~km}$ of sedimentary rock near the center of the basin.

The middle slope is less delineated by topography and structure in this record than in the CDP-1 record. The unconformity appears to persist to the lower slope, and it separates a zone of broken high-frequency reflections above from low-frequency normal faulted strata below. Along with the seismic velocities, this indicates a well-consolidated and probably metamorphosed rock below the Lima Basin fill.

The lower slope has seaward- and landward-dipping reflective sequences similar to those seen in CDP-1. A bottom-simulating reflection (BSR) is prominent along the landward part of the lower slope. Strong reflections are returned from strata in the subduction zone. The front of the margin has a seafloor topography indicating faults, but the subsurface structure indicated by reflections is not clear.

\section{Central Peru Record (CDP-2)}

The tectonic structure of the central Peru margin has been extensively studied since the Nazca Plate Project (Kulm et al., 1981; von Huene et al., 1985; Kulm et al., 1986). The transect of geophysical data that includes CDP-2 (Fig. 4) begins near the edge of the shelf along the structural high forming the seaward flank of Trujillo Basin. Dredging of the structural high has yielded crystalline rock of the Peruvian continent (Kulm et al., this volume). The top of the crystalline crust can be followed across the upper slope along the base of a high-amplitude reflective sequence (Fig. 2) that corresponds to Eocene strata recovered at Site 683 (Site 683 chapter, this volume). Resting on the Eocene is a seismically featureless layer, shown by drilling to consist of middle Miocene rock, capped in turn by a sequence of high-amplitude reflections that probably represent the unconformity between middle and upper Miocene sediment penetrated at Site 683. Above these high-amplitude reflections are reflections structured differently from those below. The antiforms and synforms look like tectonic structures but are not seen in the less-structured underlying reflections. The lack of structure in the underlying strata suggests that the lack of structure in the upper strata has a sedimentary, rather than totally tectonic origin. These upper structures can be compared with those of sediment origin in the CDP-1 and 1017 records. A BSR (CDP-450, $2.5 \mathrm{~s}$ ) indicates a source of organic-rich sediment swept from a 
nearby zone of coastal upwelling. At the base of the upper slope, the upper sediment sequence thins to a small fraction of its maximum thickness.

The midslope terrace corresponds to a structural division between the continental crust and an accretionary complex (Fig. 4). This terrace is devoid of strong reflections (Fig. 2) despite clear imaging of the subducting sediment at a depth of about 9 s. The irregular low-amplitude reflections beneath the seaward side of the terrace dip landward, as do the reflections in the accretionary complex. However, without sampling we cannot be sure whether these are accreted beds, upturned continental crust, or slope deposits. The possibility that continental rocks may underlie the terrace is underscored by the recovery of crystalline basement from dredge sites on the lower slope (Kulm et al., this volume).

The lower slope encompasses the accretionary complex (von Huene et al., 1985) with landward-dipping reflections overlain by a cover of reflections paralleling the slope and underlain by subhorizontal reflections. Here, migration has clarified a strong BSR that parallels the slope (Fig. 2). CDP-2 crosses a large subducting ridge offset by a transverse fault (which has just entered the trench axis) (Bourgois et al., 1986; Prince and Kulm, 1975) that distorts the structure of the trench axis and the deformation front. The clarity of the seismic image decreases landward, as is common in accretionary complexes. Underplated sediment is suggested by the faint subhorizontal reflections above the subducting igneous oceanic crust. Local sediment-filled topographic lows can be seen in the subducting oceanic crust.

\section{Lines Across CDP-2}

Three short lines acquired from the Jean Charcot cross CDP2 (Figs. 4 and 5). The shallowest, Line 15, crossed a location at the steep scarp marking the base of the upper slope (Figs. 2 and 4). The line transects obliquely across a steep slope, and the sloping seafloor scatters much of the energy returning from the seismic source. Seismic imaging also was difficult because of the landward dip of the reflective horizons, as seen at the intersection of CDP-2 and Line 15. In the southern part of record 15 , the base of the Neogene section is clearly imaged; however, that basal reflection becomes weak toward the north. Otherwise, few strong reflections are returned from the underlying rock (beneath $6 \mathrm{~s}$ ) consistent with the reflections in CDP-2. Faint reflections between 8 and $9 \mathrm{~s}$ may be from subducted sediment.

Line 16 crosses CDP-2 at the juncture of the middle and lower slopes (Figs. 4 and 5). Where the lines cross, CDP-2 displays landward-dipping reflections above subhorizontal reflections at 8 to $9 \mathrm{~s}$. Record 16 also shows faint low-frequency reflections at 8 to $9 \mathrm{~s}$, above which most of the reflections are short and irregular. A band of higher-amplitude reflections about $0.75 \mathrm{~s}$ beneath the seafloor, which are best displayed in the northern part of the record, may indicate the base of the slope deposits.

Line 17 crosses CDP-2 on the lower slope, and the record definitely crosses the accretionary complex (Figs. 4 and 5). Where the lines cross, CDP-2 shows faint landward-dipping reflections underlain by a narrow band of high-amplitude reflections at $9 \mathrm{~s}$. Line 17 shows the same reflections at the crossing. In record 17, CDP-2 appears to be in a broad channel with some ponded sediment. Slope deposits are difficult to distinguish from the accreted sediment in record 17. Since the slope deposits occur in beds subparallel to the seafloor, they should be imaged better than the landward-dipping beds; however, only the uppermost reflections near the seafloor have a better image. Thus, slope deposits may be thin. In the southern part of the record, an exceptionally strong BSR is indicated by sharp continuous reflections. At $9 \mathrm{~s}$, strong reflections in a narrow, sharply defined zone indicate a thin, subducting sediment section here.

\section{Northern Record (CDP-3)}

The structure beneath the middle and lower slopes along CDP-3 differs from that along the central and southern corridors (Figs. 6 and 2). The upper slope has a similar structure, but the sediment sequence is much thicker. That sediment sequence has an upper unit above a band of high- amplitude reflections that thickens seaward. The basal high-amplitude reflections merge into an angular unconformity at the seaward end of the upper slope. Thus, the configuration of the sediment body is much like that of CDP-2. Shepherd and Moberly (1981) inferred that the upper sediment sequence was of Neogene age. Below are older sediments up to $5 \mathrm{~km}$ thick that are inferred to range in age from Cretaceous to Eocene. At the base of the upper slope, units of Eocene age or older have been tilted landward or, alternatively, a block of landward-dipping strata have been juxtaposed against the seaward-dipping sequence. The upper slope is cut by numerous normal faults with vertical displacement of tens to hundreds of meters, as was seen in the central and southern areas (Figs. 3 and 4).

The upper slope is separated from the middle slope by a large curvilinear fault (Bourgois et al., 1986) whose subsurface expression was masked in earlier reprocessed versions of CDP-3 (Miller et al., 1986). Along that fault, a block about $10 \mathrm{~km}$ wide and at least $20 \mathrm{~km}$ long has detached from the upper slope (Bourgois et al., 1986; von Huene et al., 1985). The seafloor of the midslope block has been rotated back about $4^{\circ}$ along CDP3 (Fig. 2). Despite its size, this fault was not well imaged in CDP-3, perhaps because of seafloor irregularities, but the Seabeam morphology provides compelling evidence. The seaward face of the detached block is a 1-km-high scarp formed by slumping (Bourgois et al., 1986).

The lower slope has a rough seafloor that was assumed to consist of ridges until the Seabeam survey showed that these were a disorganized series of bumps. This morphology helps explain the difficulty we had of imaging the subsurface structure with the seismic technique we employed. The short discontinuous reflections support the interpretation that the lower slope is covered with slide debris from the seaward slump scarp of the midslope detached block (Bourgois et al., 1986).

\section{Lines Across CDP-3 at Proposed Drill Sites}

The migrated seismic records across CDP-3 were converted to depth sections by applying the velocities used at corresponding crossings in CDP-3 (Fig. 7). We interpreted the time sections, made line drawings, digitized and converted to depth sections using a constant velocity depth function as defined at their intersection with CDP-3.

Line 04 crosses the upper slope parallel to strike and images the seismic stratigraphy of the seaward part of the continental crust imaged in CDP-3. The upper 0.5 to $0.7 \mathrm{~s}$ below the seafloor recorded a section of relatively high-frequency, high-amplitude reflections paralleling the seafloor (Fig. 7). At the base of this sequence is an unconformity whose buried surface is cut by canyons. The unconformity has cut across $400 \mathrm{~m}$ of section in the southern part of the line (SP 130-260). The upper sequence of reflections corresponds to the Neogene section of Shepherd and Moberly (1981) and is of similar seismic character to the Neogene section and the underlying Oligocene unconformity drilled during ODP Leg 112 .

The section immediately beneath the unconformity has $0.3 \mathrm{~s}$ of high-amplitude reflections. These overlie a lower-amplitude and frequency-reflective sequence that extends to the base of the section. These low-frequency reflections correspond to the base of the Eocene, as identified by Shepherd and Moberly (1981).

This seismic record shows the typical seismic stratigraphy of continental affinity seen in all records presented here. Specifically, the stratigraphy of the rock sequence attached to the South 

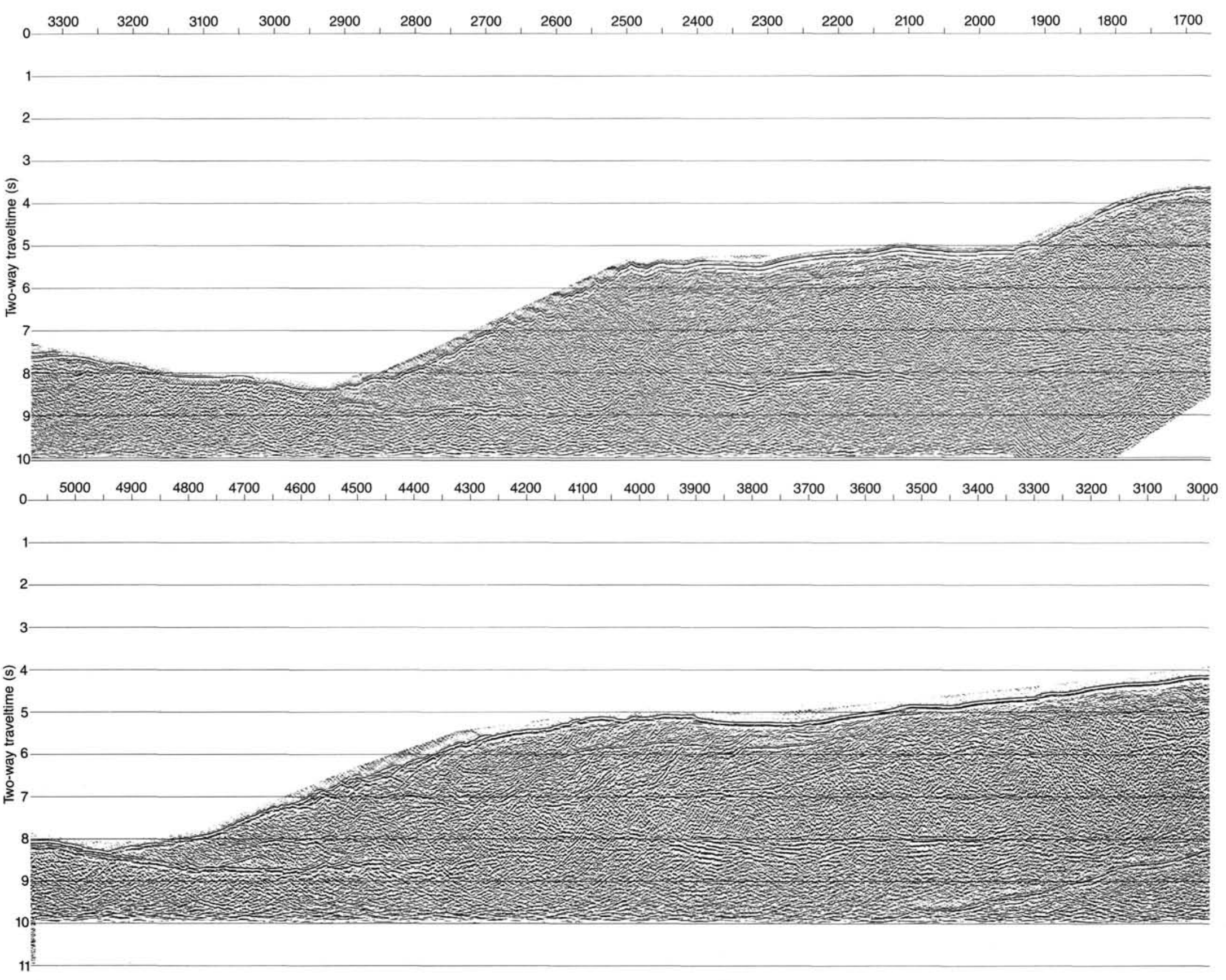


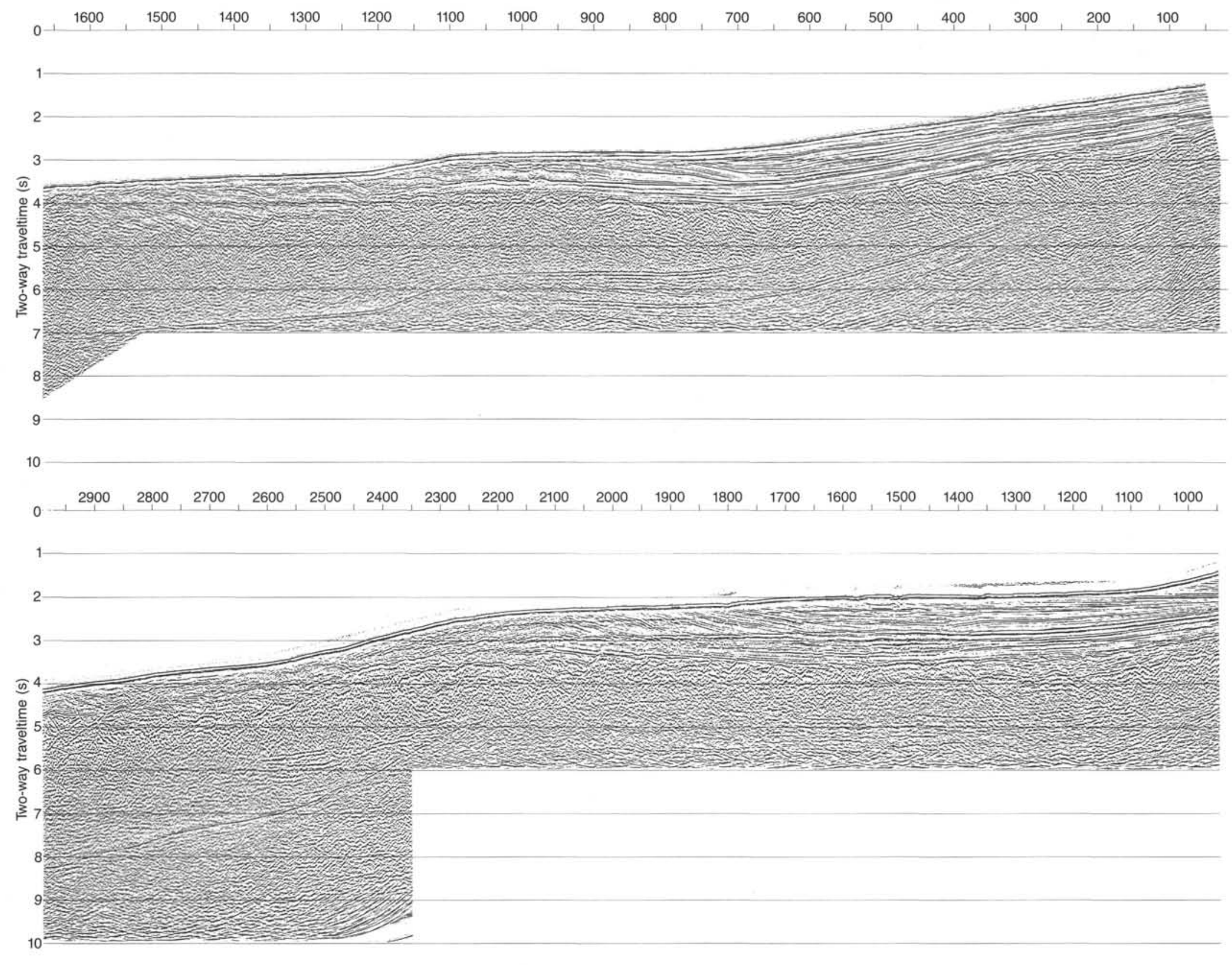




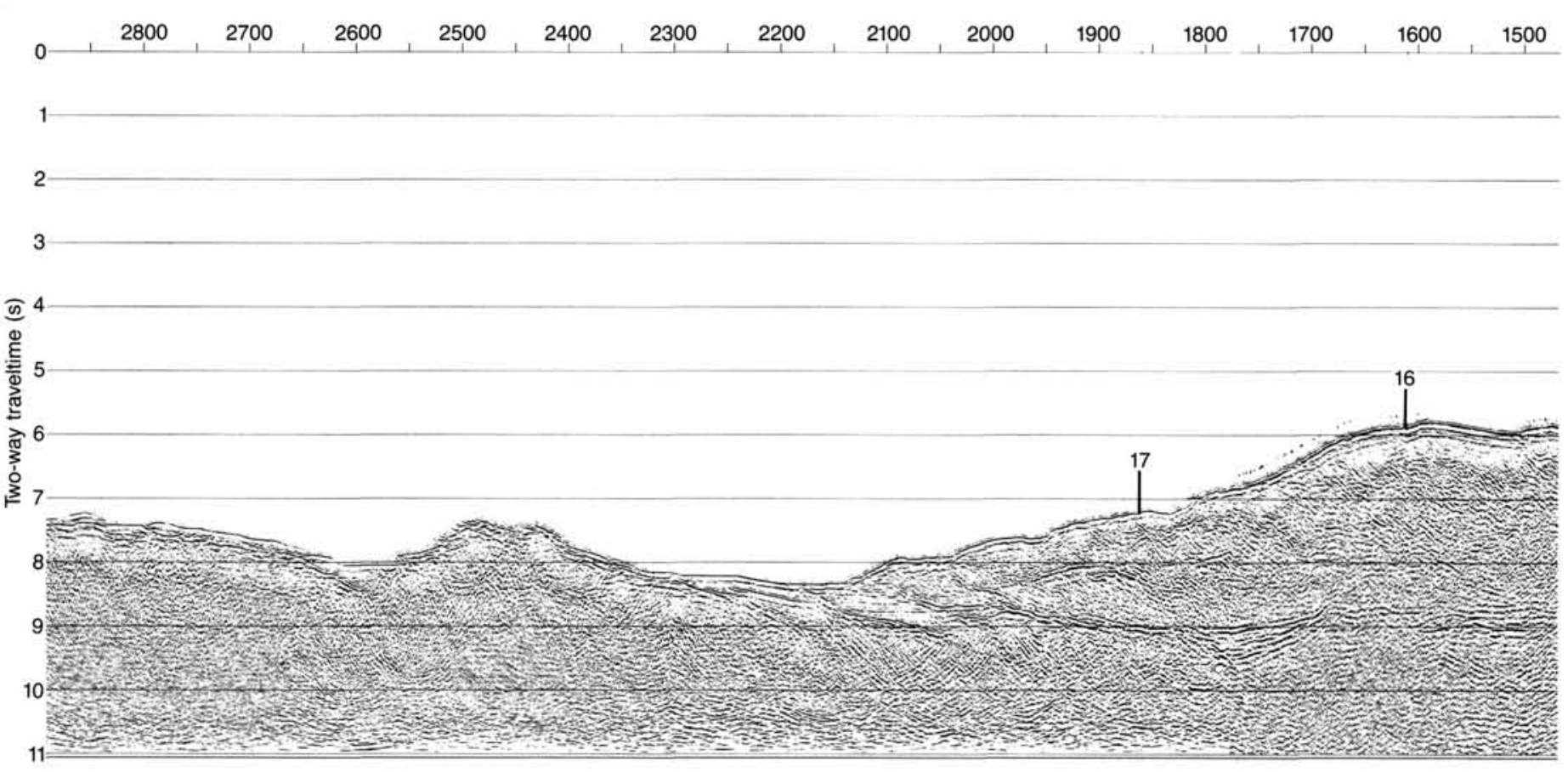
$0^{2700} \quad 2600 \quad 2500$
2400
2300
$2200+2100$
$2000+1900$
1800
$1700+\frac{1600}{1}$
1500
1400

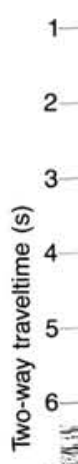

6

7 Non

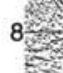

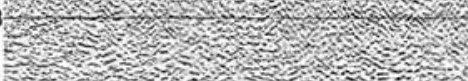

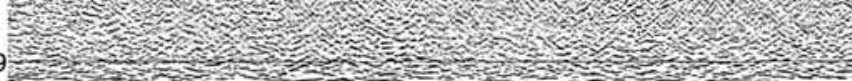

10

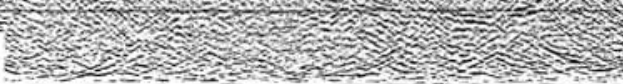



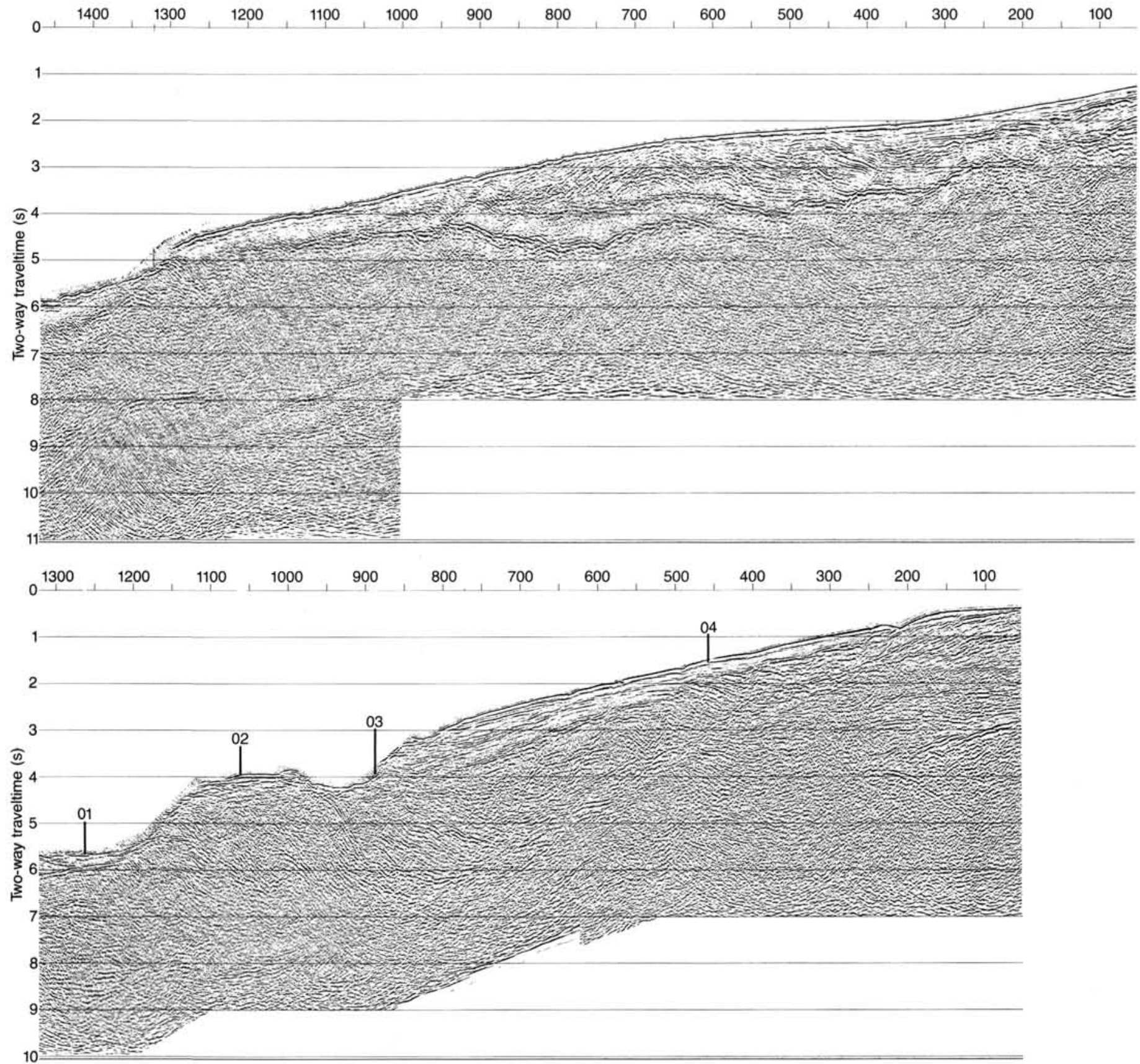

Figure 2 (continued). 


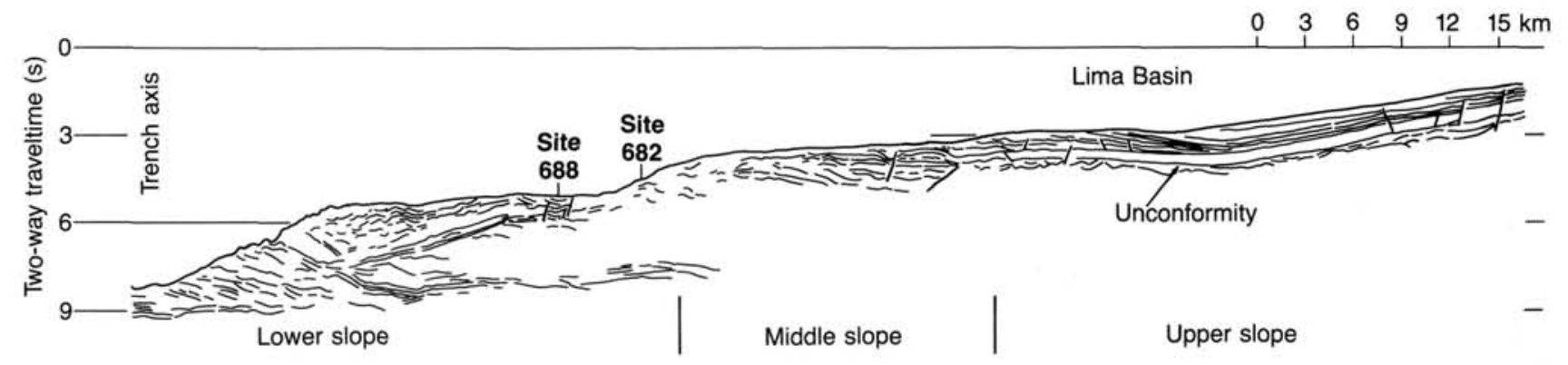

Figure 3. Line drawing of CDP-1 as a time section.

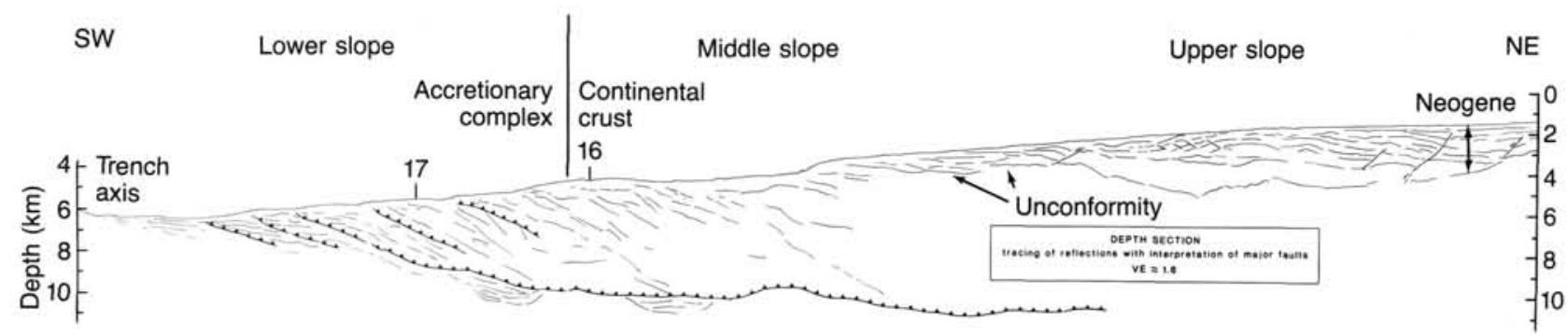

Figure 4. Line drawing of CDP-2 as a depth section (after Kulm et al., 1986). Numbers 16 and 17 at seafloor indicate positions of line crossings from records in Figure 4.

American continent before development of today's subduction zone is imaged.

Line 03 crosses a site in the fault zone along which the large midslope block was detached. Because of complex topography and structure, many reflections are obscured (Fig. 7). The southern half of the record images the section at the landward edge of the detached block. The northern half images features along the strike of the fault zone.

This record illustrates the erosive origin of the modern canyons descending the seafloor of the slope. The northernmost canyon has eroded $600 \mathrm{~m}$ into the Neogene section. Other canyons expose beds at the seafloor and, like the northern canyon, have little or no levee development.

At the southern end of the record, the Neogene section and the Oligocene unconformity at its base can be recognized (Fig. 7). Below the unconformity, between 6 and $7 \mathrm{~km}$, are strong low-frequency reflections that correspond to prominent landward-dipping reflections in CDP-3. The age of the reflectors cannot be established by tracing reflections from the area where ages were assigned, but the exposure of older rock along scarps is probable in this area.

Record 02 parallels the long axis of the detached block. It crosses the detachment fault as it curves and changes strike from parallel to the regional trend to nearly normal to the trend (Fig. 7). The $45^{\circ}$ angle between the fault and the line complicate the seismic image of the fault with many out-of-plane reflections.

The seismic reflections are grouped into three sequences. The upper sequence corresponds to the Neogene section drilled during Leg 112. The middle sequence has a seismic character similar to the Eocene and Cretaceous rocks indicated at the landward end of CDP-3 (Shepherd and Moberly, 1981). The lower sequence corresponds to the subducting sediment.

In the Neogene section, the strong reflective amplitude at the seafloor diminishes to low levels in the upper $0.3 \mathrm{~s}$ (Fig. 7). Amplitude increases again at about $0.6 \mathrm{~s}$ to mark the Oligocene unconformity. The angular discordance across the unconformity seen in CDP-3 is not apparent along strike in record 02. A BSR is seen locally at the unconformity.

The middle sequence has the seismic character of the Eocene section and consists of irregular reflections. At $6 \mathrm{~s}$, local highamplitude reflections have a character similar to the base of the Eocene at the landward end of CDP-3. In CDP-3, these reflections merge downward into landward-dipping reflections presumed to be Cretaceous in age (Miller et al., 1986). Low-frequency reflections at about $7 \mathrm{~s}$ correspond to events in the subduction zone in CDP-3.

A detachment fault was crossed at $45^{\circ}$, which produced a complex reflective pattern in the seismic record (Fig. 7). The detachment occurred on multiple faults in a 2-km-wide zone (apparent width). The diffractions from these faults are obvious in the unmigrated section; migration did not remove the strong out-of-plane reflections that continue below the depth of the decollement. The fault appears to cut through much, if not all, of the upper plate, which indicates an approximate depth of the zone of detachment that allowed the block to move downslope.

Record 01 images the front of the detached block, where still intact, as well as the area voided by slumping (Fig. 7). The intact part of the detached block has an upper sequence of moderately continuous reflections that appear characteristic of a tectonically jostled sediment sequence. Such a sequence has many small faults with minor vertical displacement and does not transmit seismic energy well. At the base of the sequence is an unconformity, presumably the Oligocene one. This section and the unconformity are missing south of the seaward detachment scarp. The slip plane on which the missing section detached and traveled downslope by mass wasting is now buried below the seafloor (Fig. 7). A strong reflection from the out-of-plane section is attributed to the detachment scarp on the basis of traveltimes and its nonconformity with surrounding reflections (Fig. 7).

Below the voided area, imaging improves because of the flatter seafloor. Reflections of relatively high amplitude $(1.5 \mathrm{~s}$ below the surface at $7 \mathrm{~s}[5.5 \mathrm{~km}]$ ) have the same depth as the base 


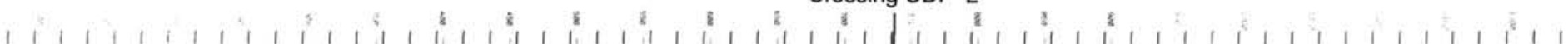

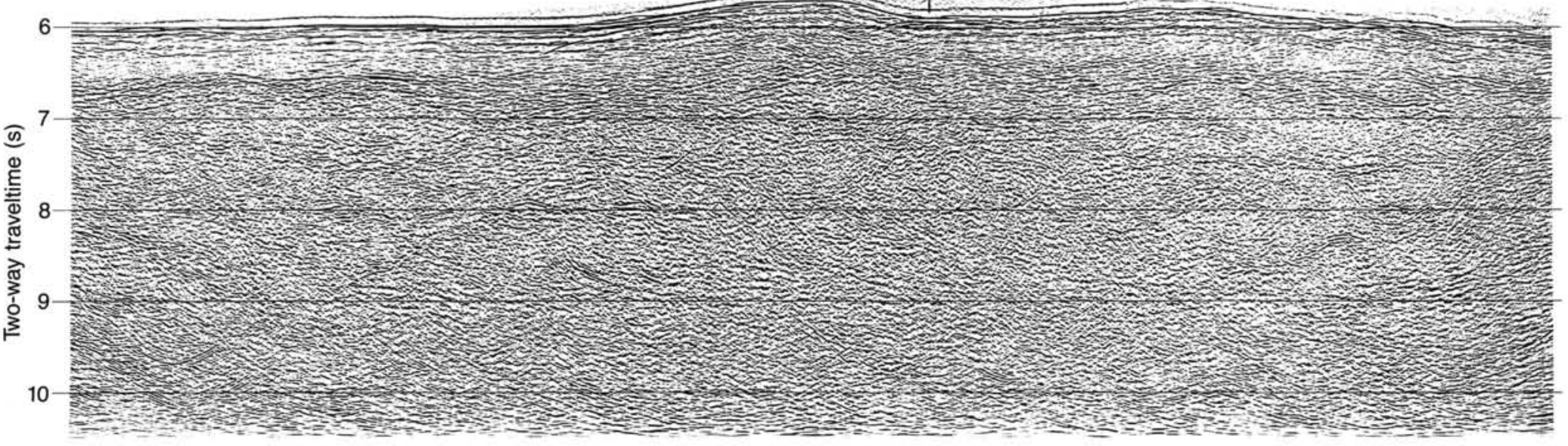

SP

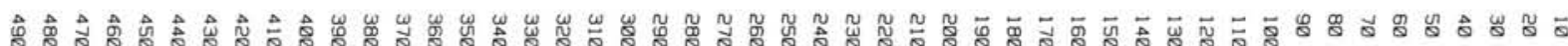

Crossing CDP.2

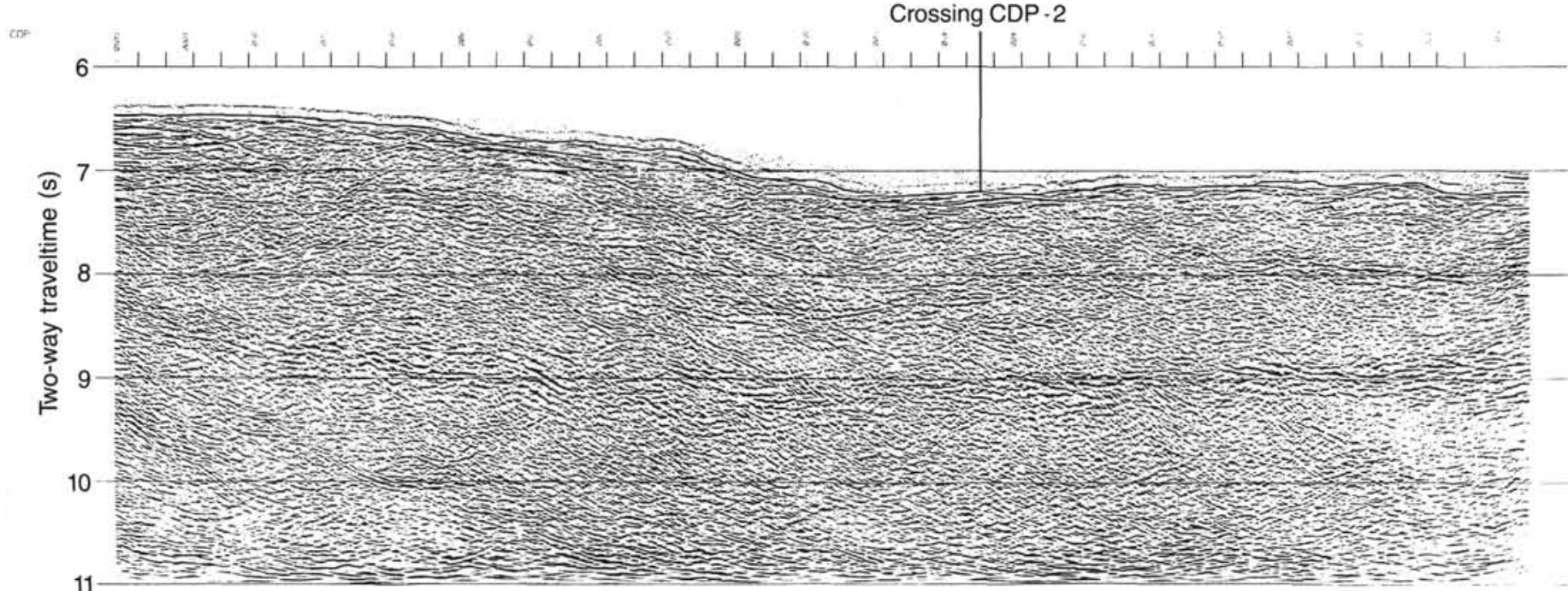

Figure 5. Migrated seismic records crossing CDP-2 shown as time sections. Crossing with CDP-2 is indicated. Vertical exaggeration 2.4 at seafloor; each shot point (SP) $=50 \mathrm{~m}$. 


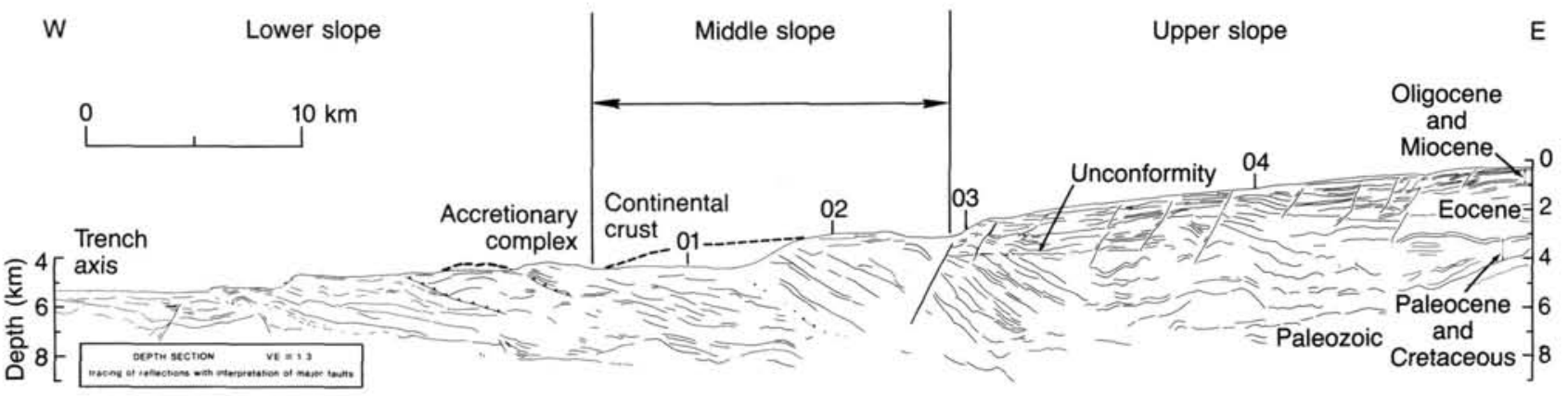

Figure 6. Line drawing of CDP-3 as a depth section (after Miller et al., 1986). Numbers 01 through 04 at seafloor indicate position of line crossings from records in Figure 7.

of the Eocene farther upslope. These reflections are generally horizontal in Peru-3 and 01. The approximate position of the top of the subducting sediment layer is near the 8-s level (Fig. 5).

In the voided area, the sediment sequence above the subducting sediment layer is essentially horizontal, and it dips gently south below the intact part of the detached block. This is characteristic of the section with continental affinity, and is consistent with the continuity of the detached block.

\section{CORRELATION OF YAQUINA BASIN WITH SITE 683}

Drilling at Site 683 showed that many of the assumptions based principally on geophysical data were incorrect. The sources of error are analyzed and discussed elsewhere (see "Geophysics" section, Site 683 chapter). Some differences in interpretation required during the study of drill cores prompted questions regarding the origin and age of the sediment section filling Yaquina Basin. These questions depend on the interpretation of reprocessed seismic record CDP-2 (von Huene et al., 1985; Kulm et al., 1986), a part of which was further processed using postcruise information from Leg 112. The area between CDP 800 and 1200 of line CDP-2 was again migrated, which gave some of the reflections a better image.

The seismic data were first migrated at constant velocity using the best stacked data from previous processing. The study of Leg 112 data showed that rock velocities were considerably less than previously assumed (see Site 683 chapter, this volume). Indeed, in the areas of greatest concern, the constant velocity migration showed better local definition of individual reflections at the slower migration velocities. The data were migrated before stacking and then stacked again, using velocities determined from the migrated data. The resulting section (Fig. 8) is compromised to show both legs of the steeply dipping reflections at conflicting dips, each of which stack best at different velocities. The accompanying interpretation (line drawing) was performed using all available information (Fig. 8).

Three unconformities (found during drilling) separate four major stratigraphic units (see Site 683 chapter, this volume). The crystalline basement is cut by an unconformity whose surface is not well defined in the seismic data, suggesting lack of a sharp velocity contrast across it. Above this unconformity are strata of Eocene age sampled in the drill holes. These have a distinctive high-amplitude and low-frequency signature, particularly at the top, where they are cut by the second unconformity between middle Eocene and middle Miocene rocks. Here, the velocity contrast is between $2.5 \mathrm{~km} / \mathrm{s}$ and 1.6 to $2.0 \mathrm{~km} / \mathrm{s}$, a contrast consistent with the 25 -m.y. hiatus between the units. Middle Miocene rocks are characterized in the seismic records by lack of distinct internal structure consistent with their massive mudstone lithology in the drill cores. The upper boundary of the middle Miocene is not well defined by amplitude because of the similar lithologies of the overlying Pliocene and Quaternary. However, the changes in seismic character and angular discordance across the upper unconformity are criteria used to infer the separation of units in our interpretation. We postulate a development of the upper Miocene section landward of Site 683 for geophysical and geologic reasons. Another unit is indicated in the seismic record (Figs. 4 and 5) landward of the part shown in Figure 8. If the whole section were Pliocene and Quaternary, the rates of sedimentation required in Yaquina Basin would be too large to be consistent with those of any other Peruvian forearc sediment body (L. Kulm, pers. comm., 1987). The Pliocene and Quaternary are irregularly stratified, especially along the seaward flank of Yaquina Basin.

Our interpretation, revised according to Leg 112 results and post-cruise seismic processing, is significant because of its relationship to the development of contourites seaward of the edge of the shelf. In CDP-1 and 1017 (Fig. 3), a sequence of similar sedimentary structures in similar water depths and of equivalent age, resembles huge structures developed by strong contour currents. Such currents would not be expected to exist only locally, and perhaps the sedimentary structures document an ancestral Humboldt-type current.

\section{STRUCTURAL FEATURES OF THE PERU MARGIN}

The reprocessed data indicate considerable variability of tectonic structure along the Peru margin. However, an underlying common regional structure is also apparent. The two common elements are (1) the crust of continental affinity beneath the middle and upper slope and (2) the accretionary complex beneath the lower slope. Here, we define continental affinity as crust that was part of the continent prior to the tectonic period during which the modern Andes were uplifted and the modern convergent margin tectonic system was initiated. Parts of that crust may have been attached to the South American continent by accretion during an earlier tectonic period. The pre-Andean age is indicated by the unconformity displayed on all records (which drilling during Leg 112 confirmed was Oligocene age). Today, this continental crust is cut by numerous normal faults, which are also apparent in the SeaMARC images (Hussong et al., this volume). Along CDP-2, sampling indicated an underlying crust of high-grade metamorphic rocks (Kulm et al., this volume), and along CDP-1, the crust has seismic velocities that indicate the same type of rock. Along CDP-3, the upper $5 \mathrm{~km}$ of the crust is stratified and Cretaceous sedimentary rocks are inferred (Shepherd and Moberly, 1981), which is consistent with the geology onshore. All records indicate a narrow boundary between the continental crust and the accretionary complex. The structures landward of that boundary are noncompressional.

Accretion, inferred from the structure beneath the lower slope, is typically displayed in CDP-2. The 10 - to $15-\mathrm{km}$-wide zone of 
accreted material rests on reflections from subducting sediments above the igneous oceanic crust. Structure is compressional below the thin cover of slope deposits.

This general structural configuration is modified by the forearc basins, which have a varied history (see Ballesteros et al., this volume). Less extensive basins having different histories and structures occur seaward of the Salaverry Basin. The disparate evolution of Trujillo and Lima basins (Kulm et al., 1984), confirmed during Leg 112 drilling, is also indicated by tectonic structure. The massive collapse and detachment of a huge block from the midslope along CDP-3 (Bourgois et al., 1986) are unique.

Conclusions confirmed by these seismic data are as follows:

1. The tectonic processes whereby the continental crust became truncated and erosion gave way to accretion are regional along the length of the Peru Continental Margin.

2. The evolution of forearc basins is localized to those basins.

3. The offshore continental crust changes character from southern to northern Peru, in that the sedimentary rock sequence is much thicker to the north.

4. Compressional tectonics dominated the deformation of the front of the margin, whereas landward of the midslope on the continental crust, deformation during the uplift of the modern Andes was predominantly noncompressional.

\section{REFERENCES}

Bourgois, J., Pautot, G., Bandy, W., Boinet, T., Chotin, P., Huchon, P., Lepenay, B., Monge, F., Monlaü, J., Pelletier, B., Sosson, M., and von Huene, R., 1986, Tectonic regime of the Andean convergent margin off Peru (SEAPERC cruise of the R/V Jean Charcot, July 1986). C.R. Acad. Sci. Paris, 303:1599-1604.

Hussong, D. M., Edwards, P. B., Johnson, S. H., Campbell, J. R., and Sutton, G. H., 1976. Crustal structure of the Peru-Chile Trench; 8$12^{\circ} \mathrm{S}$ latitude. In Sutton, G. H., et al. (Eds.), The Geophysics of the Pacific Ocean Basin and its Margin: Washington, D.C. (Am. Geophys. Union), 19:71-85.

Hussong, D. M., and Wipperman, L. K., 1981. Vertical movement and tectonic erosion of the continental wall of the Peru-Chile Trench near $11^{\circ} 30^{\prime}$ S latitude. In Kulm, L. D., Dymond, J., Dasch, E. J., and Hussong, D. M. (Eds.), Nazca Plate: Crustal Formation and Andean Convergence. Geol. Soc. Am. Mem., 154:509-524.
Kulm, L. D., Prince, R. A., French, W., Johnson, S., and Masias, A., 1981. Crustal structure and tectonics of the central Peru continental margin and trench. In Kulm, L. D., Dymond, J., Dasch, E. J., and Hussong, D. M. (Eds.), Nazca Plate: Crustal Formation and Andean Convergence. Geol. Soc. Am. Mem., 154:445-468.

Kulm, L. D., Suess, E., and Thornburg, T., 1984. Subduction zone tectonics and the evolution and distribution of organic rich sedimentary facies: the Cenozoic Peru forearc region. In Garrison, R. E., et al. (Eds.), Dolomites in the Monterey Formation and Other OrganicRich Units: Bakersfield (SEPM Spec. Publ.), 41:28-48.

Kulm, L. D., Thornburg, T., and Dang, S., 1985. Drill hole stratigraphy, dredge lithologies, and sample locations. In Hussong, D. M., et al. (Eds.), Ocean Margin Drilling Program, Regional Atlas Series, Atlas 9: Woods Hole (Marine Science International), 18.

Lehner, P., Doust, H., Bakker, G., Allenbach, P., and Gueneau, J., 1983. Active margins, parts-South America Trench, Profiles P. 1304, P. 1307, and P. 1017. In Bally. A. W. (Ed.), Seismic Expression of Structural Styles: Tulsa (Am. Assoc. Pet. Geol.), Studies in Geology Series 15:3.4.2-107-3.4.2-109.

Miller, J., Hussong, D., and von Huene, R., 1986. Peru continental margin, record section 3. In von Huene, R. (Ed.), Seismic Images of Modern Convergent Margin Tectonic Structure: Tulsa (Am. Assoc. Pet. Geol.), Studies in Geology Series, 26:32-33.

Pautot, G., Bourgois, J., Sandy, W., Boinet, T., Chotin, P., Huchon, P., Lepenay, B., Monge, F., Monlaü, J., Pelletier, B., Sosson, M., and von Huene, R., 1986. Fragmentation de la plaque Nazca a l'ouest de la fosse du Perou: resultats de la campagne SEAPERC du NO Jean Charcot. C.R. Acad. Sci. Paris, 303, Serie II, 18:1651-1656.

Prince, R. A., and Kulm, L. D., 1975. Crustal rupture and initiation of imbricate thrusting in the Peru-Chile Trench. Geol. Soc. Am. Bull., 86:1639-1653.

Shepherd, G. L., and Moberly, R., 1981. Coastal structure of the continental margin, northwest Peru and southwest Equador. Geol. Soc. Am. Bull., 154:351-391.

Thornburg, T. M., 1985. Seismic stratigraphy of Peru forearc basins. In Hussong et al. (Eds.), Atlas of the Ocean Margin Drilling Program, Peru Continental Margin, Region VI: Woods Hole (Marine Science International).

von Huene, R., Kulm, L. D., and Miller, J., 1985. Structure of the frontal part of the Andean Convergent Margin. J. Geophys. Res., 90(B7):5429-5442.

Ms 112A-107 


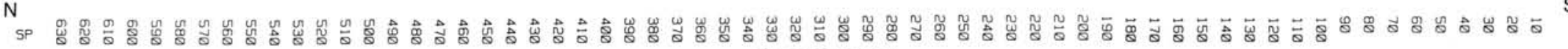

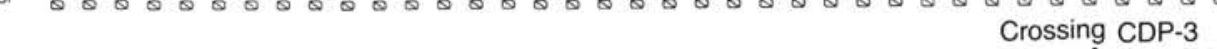

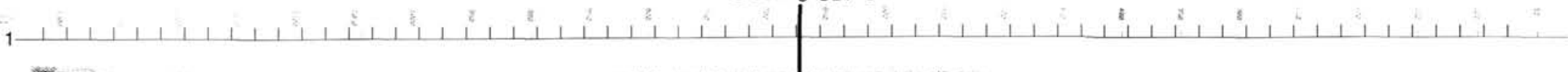

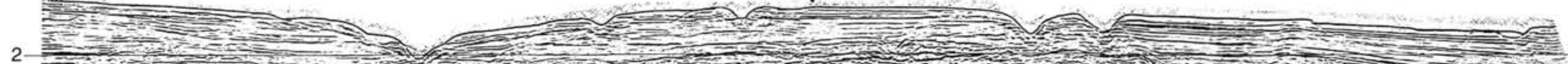

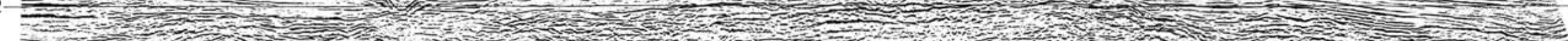

(1) V.

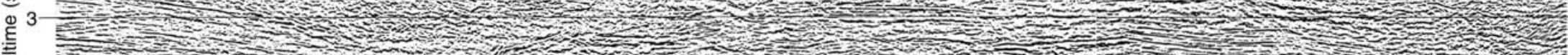

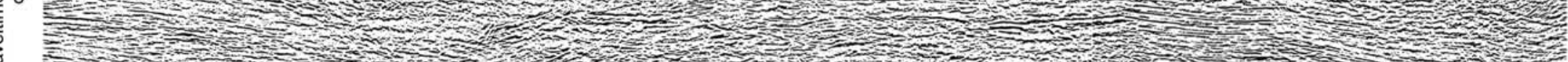

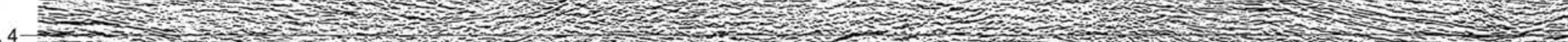

4 T.7.

tint

5 -

Thes

6

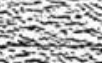

2.

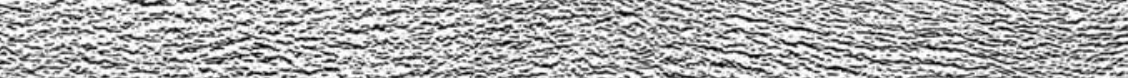

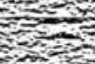

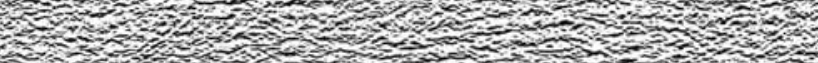

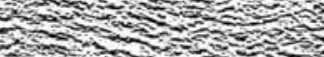

r.

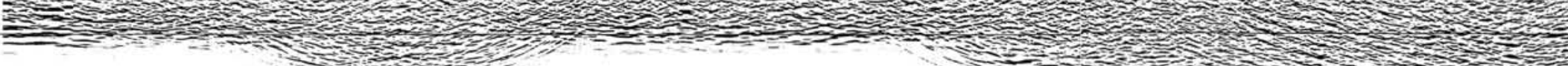

N
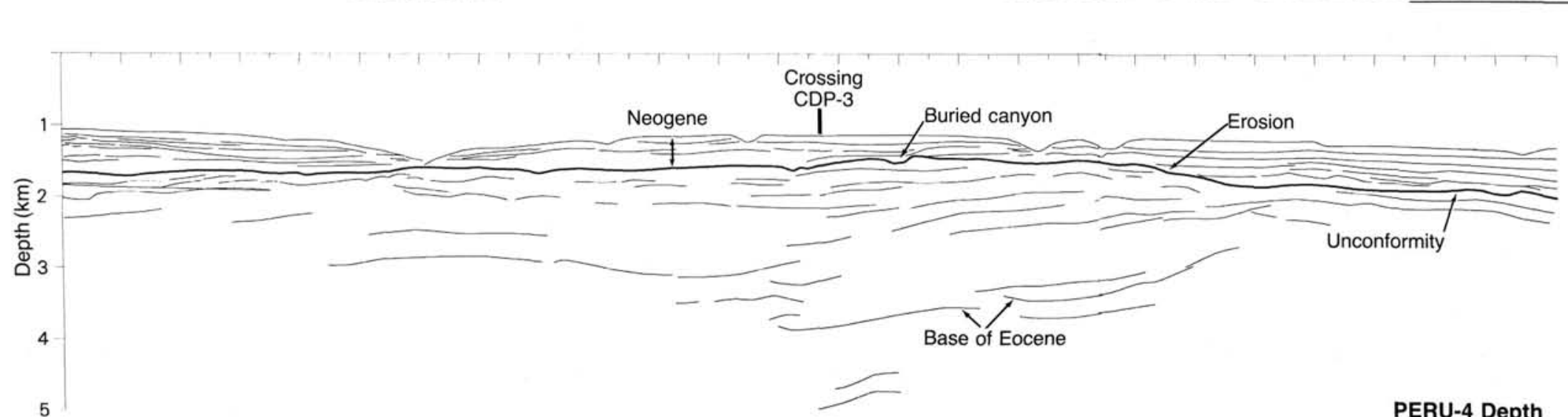

PERU-4 Depth 

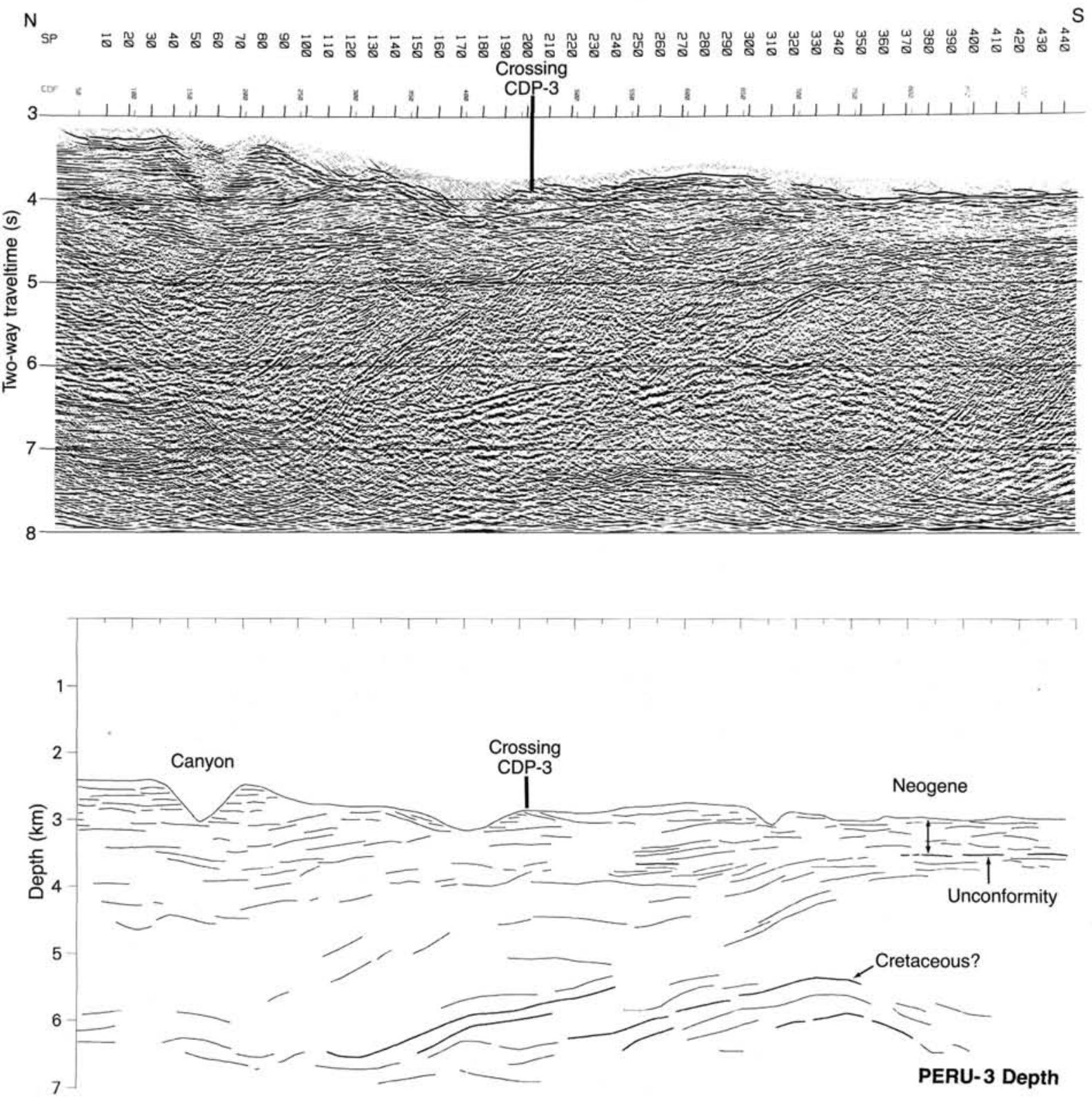

Figure 7. Seismic records crossing CDP-3 as time sections and line drawing of depth sections. Locations of crossing points are indicated. Vertical exaggeration of depth sections $=1.5 \mathrm{X} ; \mathrm{CDP}$ at 50 -m intervals. 


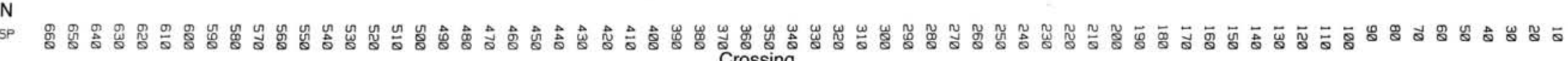

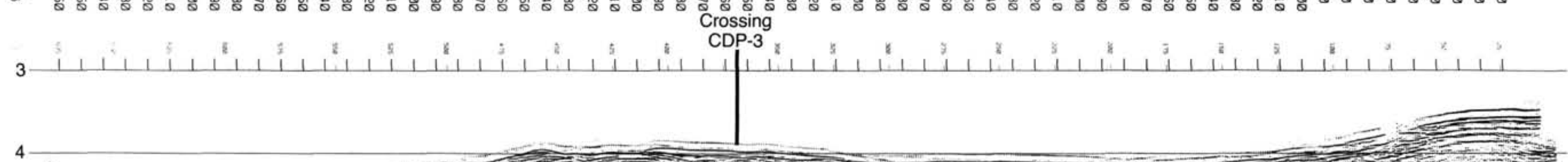
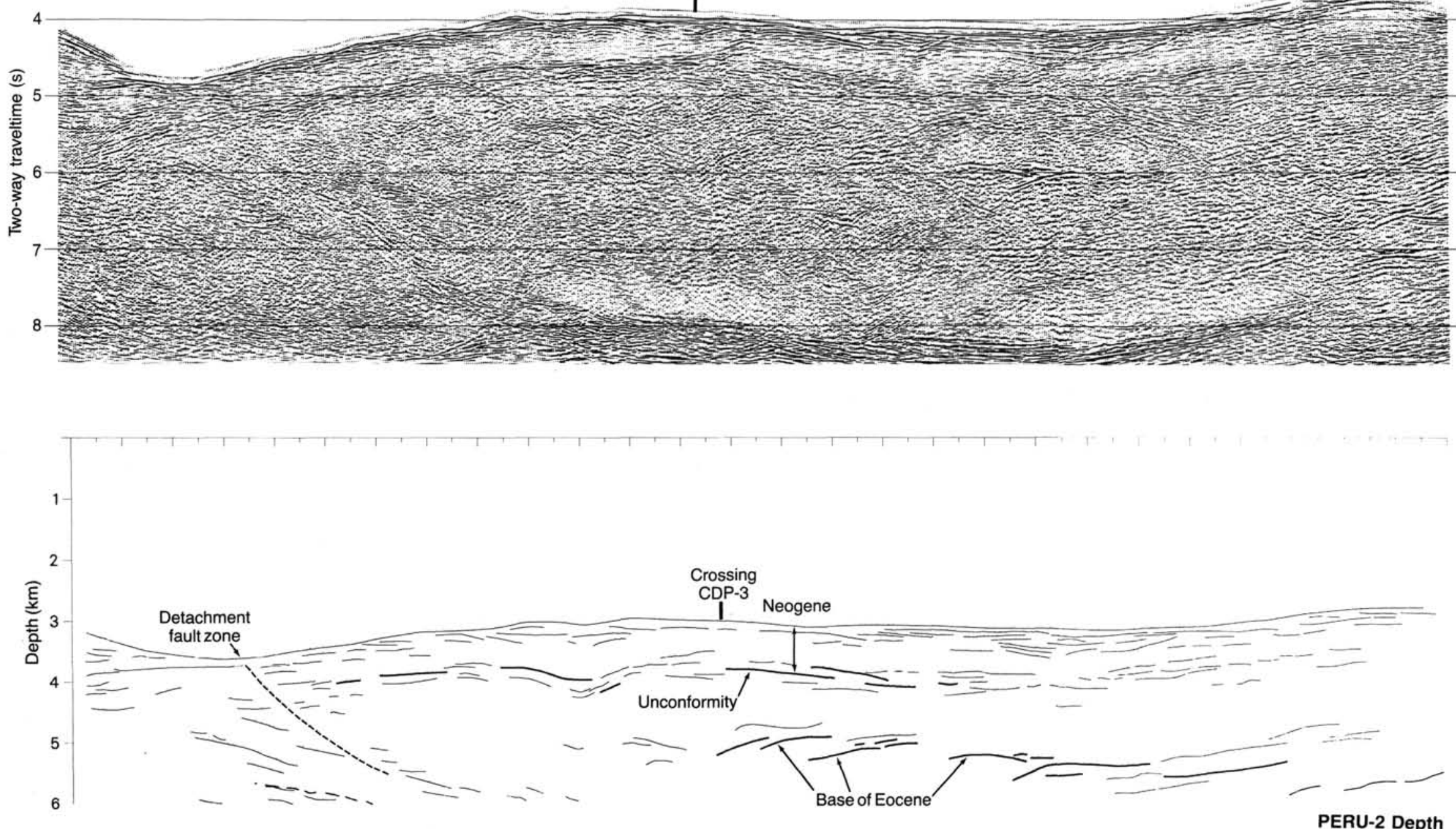

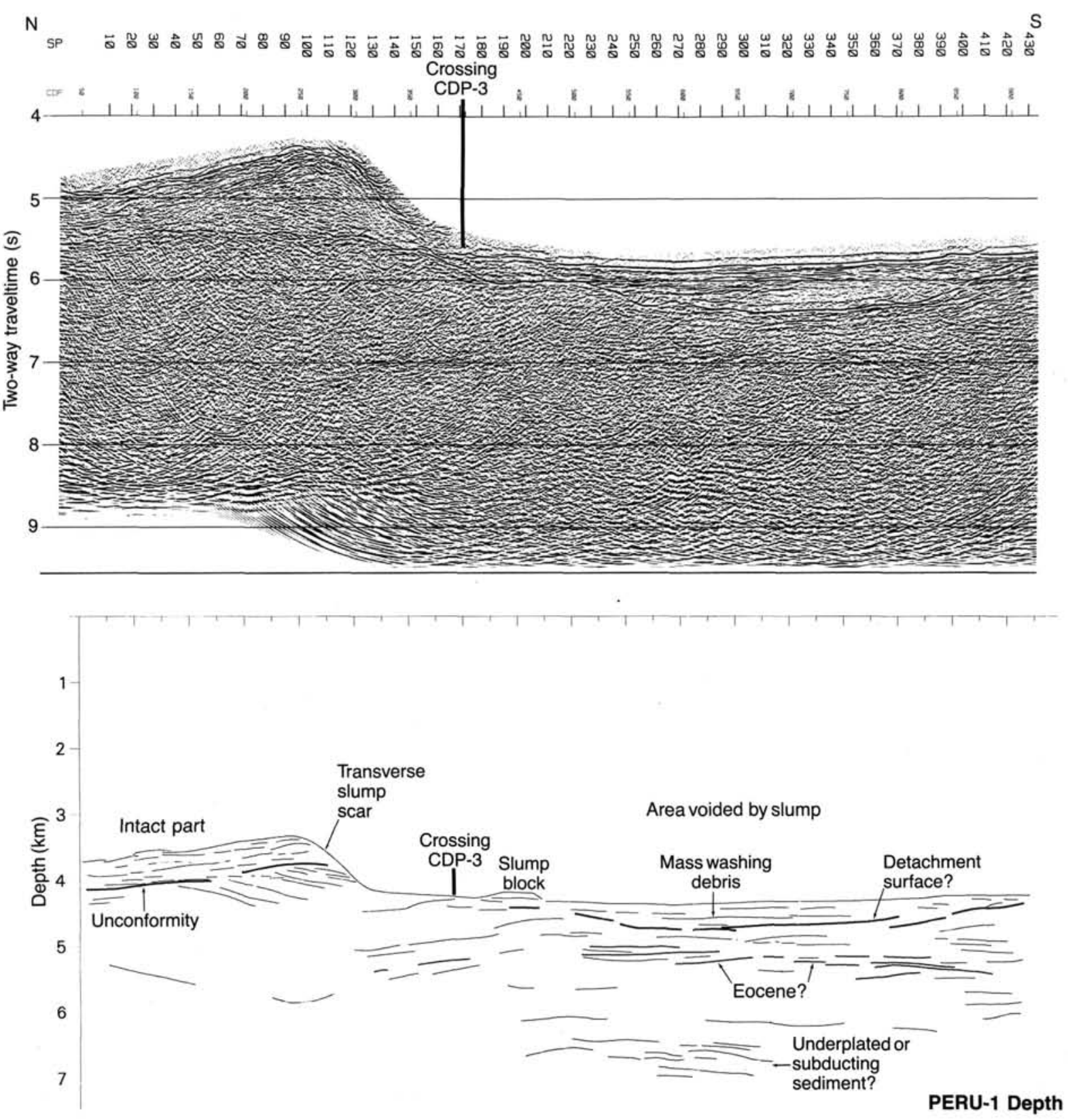

Figure 7 (continued). 


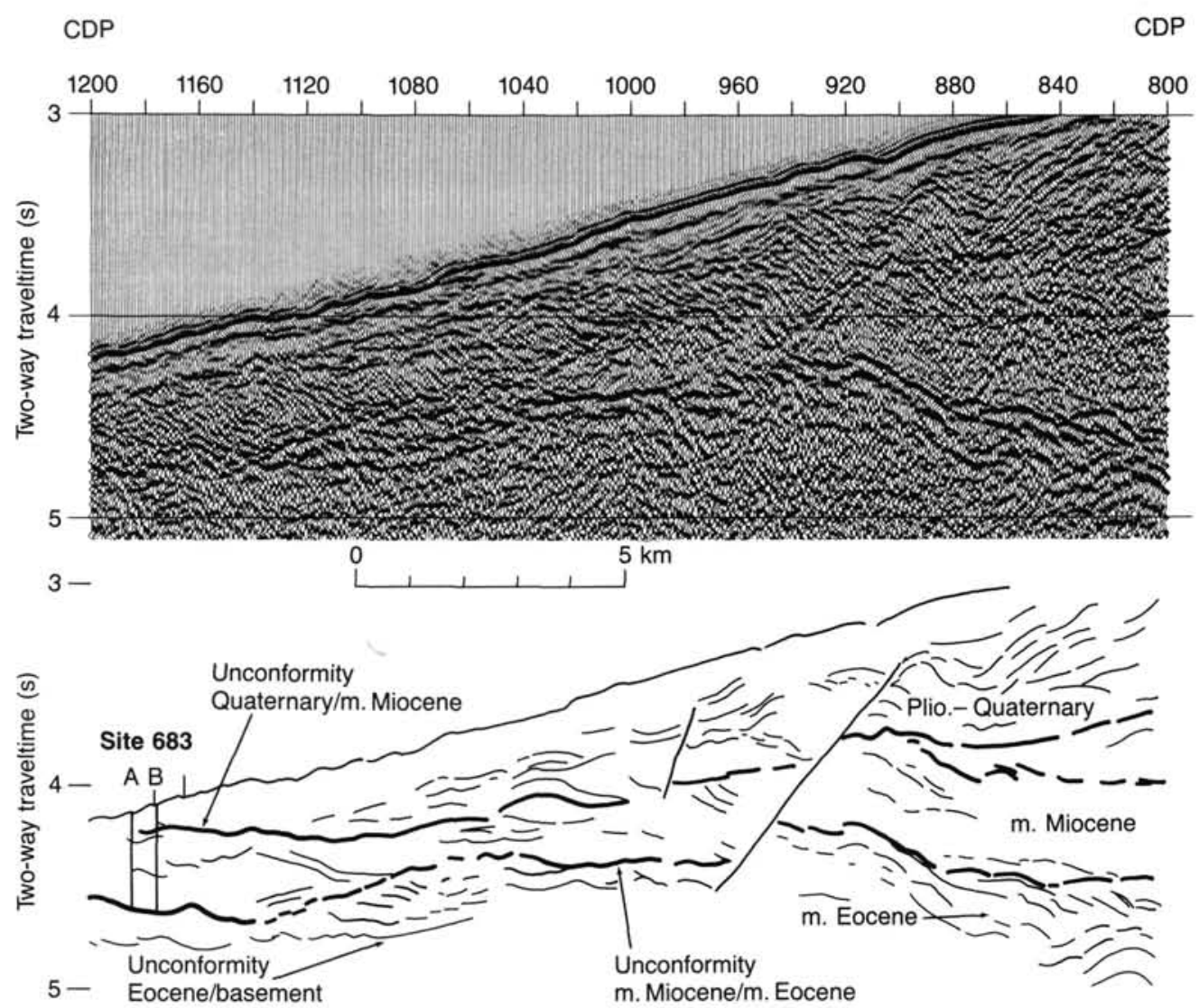

Figure 8. Remigration of part of CDP-2 after Leg 112 using results from the leg. Upper display indicates time section, lower display shows interpretation of line drawing. 